\title{
Production of Hexaric Acids from Biomass
}

\author{
Riku Sakuta and Nobuhumi Nakamura * \\ Department of Biotechnology and Life Science, Tokyo University of Agriculture and Technology, \\ 2-24-16 Nakacho, Koganei, Tokyo 184-8588, Japan \\ * Correspondence: nobu1@cc.tuat.ac.jp
}

Received: 29 June 2019; Accepted: 24 July 2019; Published: 26 July 2019

check for updates

\begin{abstract}
Sugar acids obtained by aldohexose oxidation of both the terminal aldehyde group and the hydroxy group at the other end to carboxyl groups are called hexaric acids (i.e., six-carbon aldaric acids). Because hexaric acids have four secondary hydroxy groups that are stereochemically diverse and two carboxyl groups, various applications of these acids have been studied. Conventionally, hexaric acids have been produced mainly by nitric acid oxidation of aldohexose, but full-scale commercialization has not been realized; there are many problems regarding yield, safety, environmental burden, etc. In recent years, therefore, improvements in hexaric acid production by nitric acid oxidation have been made, while new production methods, including biocatalytic methods, are actively being studied. In this paper, we summarize these production methods in addition to research on the application of hexaric acids.
\end{abstract}

Keywords: aldaric acids; biorefinery; biofuel cell; bioprocess; biorefinery; carbohydrates; electrochemistry; green chemistry; oxidation; sustainable chemistry

\section{Introduction}

The International Energy Agency defines a biorefinery as "the sustainable processing of biomass into a spectrum of marketable products and energy", which is the most comprehensive and commonly accepted definition [1]. Because inexpensive petroleum-derived chemicals are already mass produced, the production of bio-based chemicals has been limited to those with structures that are too complex for the fine-chemicals market to justify their expensive production costs [2]. However, nonrenewable resources are limited despite population growth. Accordingly, the increased consumer demand for environmentally friendly products has become a driving force for the use of biorefineries [2]. Emerging economies (e.g., the countries of Brazil, Russia, India and China (BRIC)) require increasing amounts of oil and other fossil-based products, in addition to the security of chemical and energy supplies for isolated regions such as islands [2]. Carboxylic acids have attracted considerable attention among the raw materials for bioderived chemicals. The US Department of Energy (DOE) has selected twelve chemicals from more than three hundred biomass-derived chemicals, based on cooperative research with industry and academia, to be developed using biorefinery production methods [3]. More than half of the twelve selected chemicals are carboxylic acids. Carboxylic acids obtained by the oxidation of monosaccharides and oligosaccharides are referred to as sugar acids [4-6]. The oxidation of aldose (aldohexose when the carbon number is six) at its aldehyde group to form a carboxyl group produces aldonic acid (aldohexonic acid), whereas the corresponding oxidation at its terminal hydroxy group results in a different monocarboxylic acid, (aldo)uronic acid ((aldo)hexuronic acid). Aldaric acid (hexaric acid) is a dicarboxylic acid produced by oxidizing both groups (Figure 1). Because aldaric acids have been studied for numerous types of applications, improved methods for their production are urgently needed. D-Glucaric acid, the aldaric acid of D-glucose or L-gulose, was selected by the DOE as one of the twelve chemicals [3]. Hence, this article summarizes biorefinery methods relating to aldaric acids with six carbon atoms (hexaric acids; Figure 1), including D-glucaric acid. 
<smiles>CC(O)C(C)CO</smiles>

Aldose $(n=4:$ Aldohexose $)$<smiles>CC(O)C(C=O)C(=O)O</smiles>

Uronic acid

( $n=4$ : Hexuronic acid $)$<smiles>CC(C)(CO)C(O)C(=O)O</smiles>

Aldonic acid $(n=4$ : Aldohexonic acid $)$<smiles>CC(O)C(C)C(=O)O</smiles>

Aldaric acid

( $n=4$ : Hexaric acid)

Figure 1. Structures of aldose and its acids.

\section{Classification of Aldohexoses and Hexaric Acids}

Aldohexoses have four stereocenters, resulting in sixteen configurational isomers (Figure 1). Relative-configuration classification divides these stereoisomers into eight groups with the following common names: altrose, allose, idose, galactose, glucose, gulose, talose, and mannose. In contrast, hexaric acids have the same functional group at both ends of their structure; thus, the hexaric acids of altrose and talose and those of glucose and gulose are the same compounds. Moreover, the hexaric acids of allose and galactose are meso-compounds, because of their symmetry. In short, relative-configuration classification divides hexaric acids into altraric acid, allaric acid, idaric acid, galactaric acid, glucaric acid, and mannaric acid; because allaric acid and galactaric acid are meso-compounds, the total number of configurational isomers is ten (Figure 2) [7]. Because hexaric acids have four stereochemically diverse secondary hydroxy groups and two carboxyl groups, their applications as platform chemicals have been studied as described below. Of the hexaric acids, D-glucaric, meso-galactaric, and D-mannaric acids have been the most studied as starting compounds for biorefineries, in part because the raw materials for these hexaric acids are abundant. Therefore, several compounds, such as L-mannaric acid [8,9] and D-idaric acid, $[10,11]$ which are used as the starting compounds for human immunodeficiency virus (HIV) protease inhibitors, are regarded as exceptions in this report. The focus of this article is on studies investigating the applications and production methods for D-glucaric acid, meso-galactaric acid, and D-mannaric acid. 
<smiles>O=C(O)[C@@H](O)[C@@H](O)[C@@H](O)[C@H](O)C(=O)O</smiles><smiles>O=C(O)[C@@H](O)[C@@H](O)[C@H](O)[C@@H](O)C(=O)O</smiles><smiles>O=C(O)[C@@H](O)[C@@H](O)[C@H](O)[C@@H](O)C(=O)O</smiles><smiles>O=C(O)[C@@H](O)[C@@H](O)[C@@H](O)[C@H](O)C(=O)O</smiles><smiles>O=C(O)[C@@H](O)[C@@H](O)[C@H](O)[C@@H](O)C(=O)O</smiles><smiles>O=C(O)[C@@H](O)[C@@H](O)[C@H](O)[C@@H](O)C(=O)O</smiles><smiles>O=C(O)[C@@H](O)[C@@H](O)[C@H](O)[C@@H](O)C(=O)O</smiles><smiles>O=C(O)[C@@H](O)[C@@H](O)[C@H](O)[C@H](O)C(=O)O</smiles><smiles>COC(=O)[C@H](O)[C@@H](O)[C@H](O)[C@H](O)C(=O)O</smiles><smiles></smiles>

Figure 2. Structures of hexaric acids.

\section{Applications of Hexaric Acids}

Because hexaric acids have four stereochemically diverse secondary hydroxy groups and two carboxyl groups, they have been studied since the 1950s as platform chemicals for producing chelating agents and corrosion inhibitors [10-21], precursors for polyamides [22-36], polyesters [37-41], polyanhydrides [42], polycations [43], coordination polymers including metal-organic frameworks [44-48], pendant polymers [49], macromolecules [50,51], cross-linkers in hydrogels [52], medicines [8-11,49,51,53], and other compounds including platform chemicals, like adipic acid and furan dicarboxylic acid [54-62].

\subsection{Monomers}

The use of hexaric acids as monomers produces polycondensates that are nontoxic, biodegradable, and more hydrophilic than those derived from petrochemicals [36]. Research on polyamide syntheses derived from hexaric acids started in the 1950s [22] and continues, particularly in the laboratory of Kiely. This group has synthesized polyamides from three monomers, D-glucaric acid, meso-galactaric acid, and D-mannaric acid, to investigate the influence of stereochemistry on the physical properties of polymers [31]. The polyamides were synthesized in methanol from either a hexaric acid diester or a methylated hexaric acid lactone, which were synthesized by a condensation reaction of a hexaric acid and methanol, with even-number-chain-length alkylenediamines having two to twelve carbon atoms as the monomers (Figure $3 \mathrm{~A}-\mathrm{C}$ ). 
(A)<smiles>COC(=O)C(O)[C@H](O)[C@H](O)[C@H](O)C(=O)OC</smiles>

dimethyl meso-galactarate

(B)

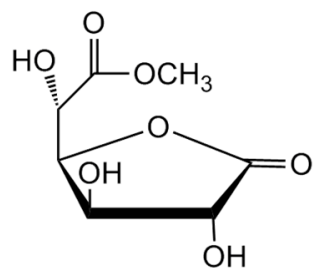

methyl D-glucarate 1,4-lactone

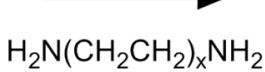
$\mathrm{X}=1-6$<smiles>N[14CH2][14CH]=[14C](N)N</smiles>
$x=1-6$

(C)

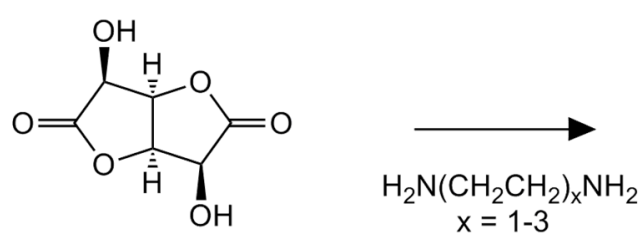

D-mannaro-1,4:6,3-dilactone

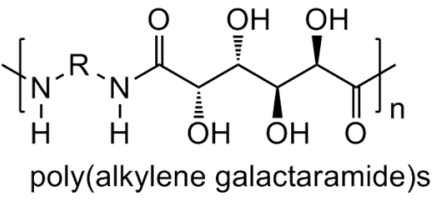

$\mathrm{R}=\left(\mathrm{CH}_{2} \mathrm{CH}_{2}\right)_{x}, \mathrm{x}=1-6$<smiles>CC(C)(C)NPNC(=O)C(O)C(O)C(O)C(O)C(O)C(C)(C)C(=O)O</smiles>

$\mathrm{R}=\left(\mathrm{CH}_{2} \mathrm{CH}_{2}\right)_{\mathrm{x}}, \mathrm{x}=1-6$

(C)

(D)<smiles>COC(=O)[C@@H](O)[C@@H](O)[C@@H](O)[C@@H](O)[C@H](O)[C@@H](O)C(=O)OC</smiles>

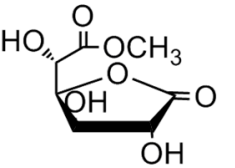

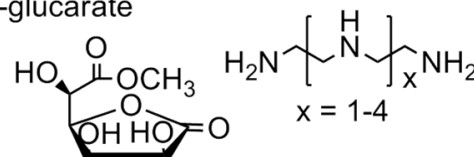

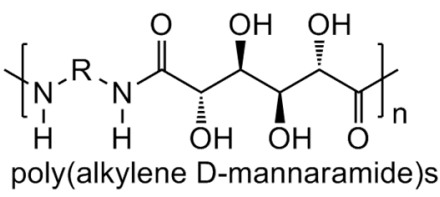

$\mathrm{R}=\left(\mathrm{CH}_{2} \mathrm{CH}_{2}\right)_{x}, \mathrm{x}=1-3$

methyl D-glucarate methyl D-glucarate

1,4-lactone 6,3-lactone

(E)<smiles>COC(=O)[C@@H](O)[C@H](O)[C@@H](O)C(=O)OC</smiles>

dimethyl meso-galactarate

(F)<smiles>O=C1O[C@@H]2[C@@H](OC(=O)[C@@H]2O)C1O</smiles>

D-mannaro-1,4:6,3-dilactone<smiles>[X]C(N)(CN)CNCC(C)(C)N</smiles>
$x=1-4$

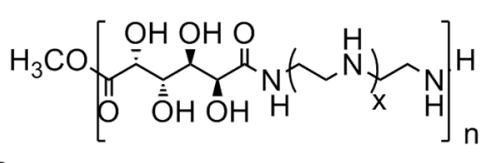

Poly(galactaramidoamine)s

$$
x=1-4
$$

$$
x=1-4
$$

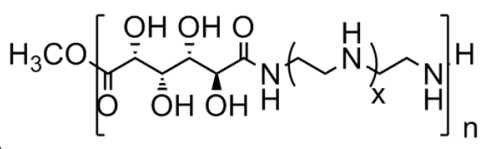

Poly(D-glucaramidoamine)s 
A comparison between poly(alkylene galactaramide)s synthesized from meso-galactaric acid and poly(alkylene D-glucaramide)s from D-glucaric acid revealed that the melting points of poly(alkylene galactaramide)s were all higher than those of poly(alkylene D-glucaramide)s when the length of the alkylenediamine used was the same. Furthermore, it was found that, while the poly(alkylene D-glucaramide)s composed of alkylenediamines with two and four carbon atoms were water soluble, only the poly(alkylene galactaramide) produced from ethylenediamine was water soluble (Table 1). meso-Galactaric acid has a highly symmetric structure in which the carbon chain extends in a zigzag, bearing alternating hydroxy groups as confirmed by crystallography [63]. Through these hydroxy groups, meso-galactaric acids can interact via intermolecular hydrogen bonding [63]. In the case of D-glucaric acid, which is asymmetric, the 1,3-steric repulsions between the hydroxy groups at the C2 and $\mathrm{C} 4$ positions result in a bent molecular structure rather than an extended-zigzag structure [64]. Kiely et al. reported that the stereochemical differences between hexaric acids were responsible for the differences in the physical properties between the polyamides [31]. Because the galactaric acid moiety is extended, poly(alkylene galactaramide)s readily become linear. The adoption of a linear structure could increase both the hydrogen bonding between the galactaric acid moieties and the van der Waals forces derived from alignment of the alkylenediamine moieties. In contrast, poly(alkylene D-glucaramide)s tend to form a bent structure because the D-glucaric acid moiety is bent, preventing attractive forces from developing between the polymers. The authors concluded that the differences in interchain attraction underlay the differences in melting points and water solubility between these compounds. Poly(alkylene D-mannaramide)s have head-to-tail type stereoregularity because of the hydroxy groups bound symmetrically along the carbon chain of D-mannaric acid moiety. Because the 1,3-steric repulsions are not present in D-mannaric acid, the authors assumed that the acid tends to form extended-zigzag structures, resulting in melting points and water solubility similar to those of poly(alkylene galactaramide)s. Polymer syntheses that take advantage of physical property differences derived from the different stereochemical properties of aldaric acids have been reported. For example, a polymer derived from D-glucaric acid has an amorphous nature because the attractive interactions between the polymers are weak, which is advantageous for synthesizing materials that have good film-forming and adhesive properties [30]. The nature of meso-galactaric acid-derived polymers, which tend to form linear structures, was used to improve the thermophysical properties of polyanhydrides [42]. Henkensmeier et al. reported that they were able to change the physical properties of a polymer by combining D-glucaric acid and meso-galactaric acid; their method allowed for precisely adjusting the glass transition temperatures of silicone surfactants [34].

Table 1. Isolated yields, melting points, and water solubility of poly(alkylene hexaramide)s [31]. The original tables have been combined into this table.

\begin{tabular}{ccccc}
\hline Polymers & Yield & $\mathbf{m p}\left({ }^{\circ} \mathbf{C}\right)^{\mathbf{a}}$ & Water Solubility $^{\mathbf{b}}$ & ${\boldsymbol{\boldsymbol { M } _ { \boldsymbol { n } }}}^{\mathbf{c}}$ \\
\hline Poly(ethylene D-glucaramide) & 93.3 & 185 & Yes & 2036 \\
Poly(tetramethylene D-glucaramide) & 88.3 & $192-195$ & Yes & 2725 \\
Poly(hexamethylene D-glucaramide) & 89.4 & $192-194$ & No & 2552 \\
Poly(octamethylene D-glucaramide) & 86.8 & $195-200$ & No & 3562 \\
Poly(decamethylene D-glucaramide) & 89.8 & $200-205$ & No & 3218 \\
Poly(dodecamethylene D-glucaramide) & 93.9 & $200-205$ & No & 2730 \\
Poly(ethylene galactaramide) & 90.1 & 205 & VS & 702 \\
Poly(tetramethylene galactaramide) & 82.1 & 230 & SS & 1179 \\
Poly(hexamethylene galactaramide) & 85.2 & 228 & NS & 2320 \\
Poly(octamethylene galactaramide) & 79.4 & 230 & NS & 4920 \\
Poly(decamethylene galactaramide) & 82.2 & 230 & NS & 2560 \\
Poly(dodecamethylene galactaramide) & 87.4 & 225 & NS & 2356 \\
Poly(ethylene D-mannaramide) & 72 & $180-206$ & VS & 1410 \\
Poly(tetramethylene D-mannaramide) & 77 & $194-201$ & VS & 1249 \\
Poly(hexamethylene D-mannaramide) & 68 & $205-210$ & NS & 1247 \\
\hline
\end{tabular}

a All polymers decomposed upon melting. $\mathrm{mp}=$ melting point. ${ }^{\mathrm{b}} \mathrm{VS}=$ very soluble; $\mathrm{SS}=$ slightly soluble; $\mathrm{NS}=$ not soluble. ${ }^{\mathrm{c}} M_{n}=$ number average molecular weight. 


\subsection{Application of Hexaric Acid Polymers: An Example}

Applications of synthetic polymers, including as drug delivery carriers, have been reported. Liu and Reineke et al. reported polyamides composed of hexaric acid moieties and secondary amines as the repeating units that could replace viruses as nucleic acid medicine carriers (Figure 3E-G) [35]. Conventionally, polyethylene imines (PEIs) and chitosan have been studied as substitutes for viruses. The PEIs used in this study showed high gene-transport efficiencies in almost all cell lines used in the study, and chitosan displayed no cytotoxicity. However, each polymer also had a drawback: longer PEIs showed strong cytotoxicities, and chitosan had an inferior transport efficiency. The synthesized polyamides in this study had an abundance of secondary amines and hydroxy groups, and showed both good biocompatibilities and high transport efficiencies. Similar to PEI and chitosan, the synthesized polyamides formed viral-like electrostatic complexes with plasmid DNA (pDNA), termed polyplexes, which were taken up through the endocytotic pathway and dissociated within the endosome. The stereochemistry between the hexaric acid moiety and the number of amines in the repeating units greatly changed the binding affinity to pDNA, its volume in the binding complex, and its transportation efficiency into cells. The polymers derived from meso-galactaric acid showed higher transport efficiencies than those derived from D-glucaric acid or D-mannaric acid.

\subsection{Macromolecules}

Macromolecules derived from hexaric acids have also been studied for use in drug delivery systems [50,51]. Gu et al. synthesized amphiphilic macromolecules by bonding the hydroxy groups and a terminal carboxylic group of the hexaric acids, commencing with meso-galactaric acid, to alkyl chains and poly(ethylene glycol)s, respectively (Figure 4) [51].

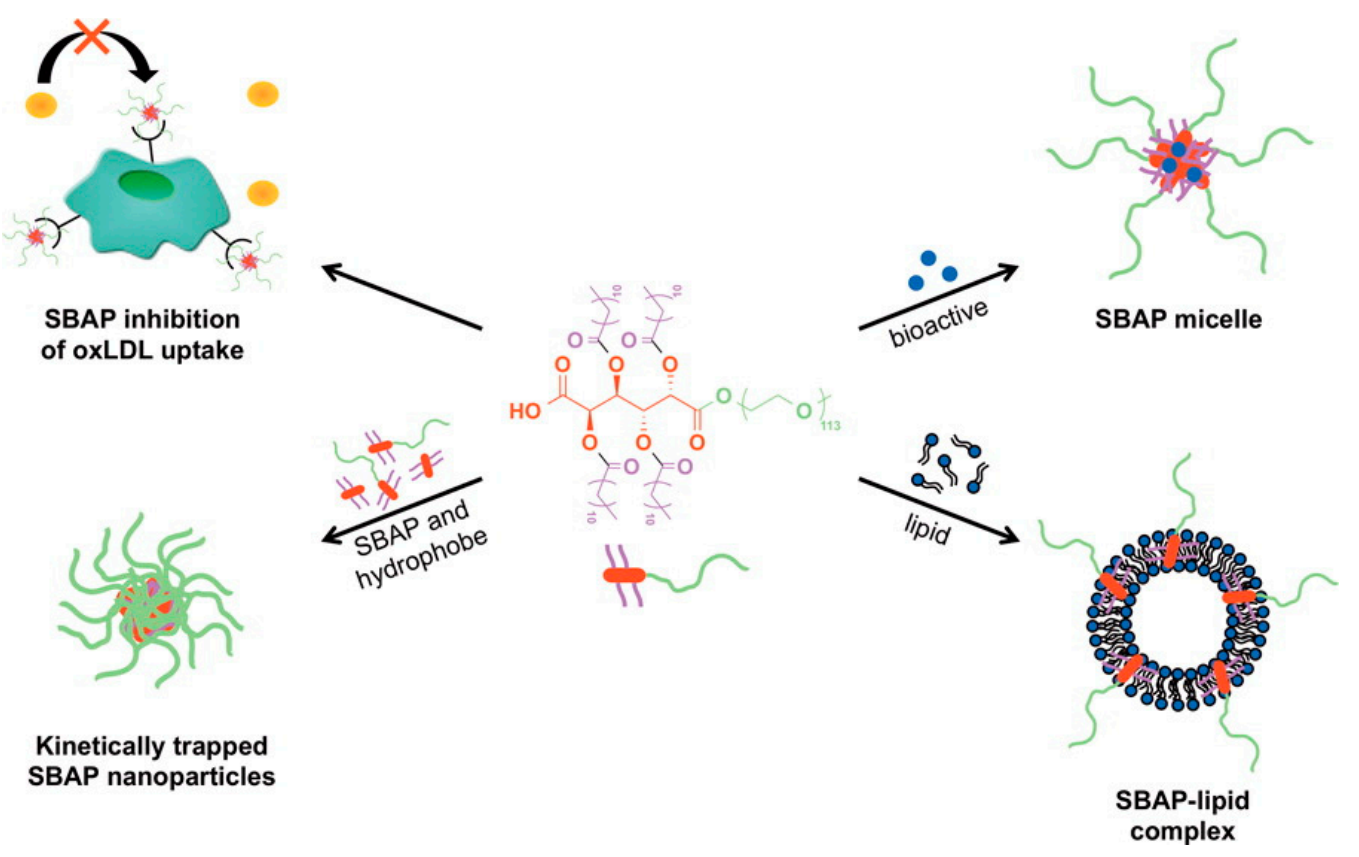

Figure 4. Sugar-based amphiphilic polymers (SBAPs) for biomedical applications [51]. oxLDL = oxidized low-density lipoproteins.

The resulting amphiphilic macromolecules, which showed low critical micelle concentrations, were studied for use as drug carriers for hydrophobic anticancer agents and gene therapy agents. Furthermore, these amphiphilic macromolecules were found to treat atherosclerosis by preventing macrophage intake of oxidized low-density lipoproteins. 


\subsection{Chelating Agents, Coordination Polymers and Metal-Organic Frameworks}

Complexation of the carboxyl and hydroxy groups of hexaric acids with metals has been used in applied research. For example, such products have been investigated for use as agents to remove metals from polluted environments and incinerator plants, as corrosion inhibitors, and as Ca-sequestering agents, several of which have been commercialized [6]. The chelation ability of hexaric acids was exploited for the synthesis of coordination polymers and metal-organic frameworks (MOFs). Abrahams et al. synthesized coordination polymers derived from hexaric acids and metals. For example, they used D-glucaric acid and $\mathrm{Zn}$ to form a coordination polymer with two types of isolated, parallel channels, one of which was hydrophilic and the other hydrophobic [44]. The hydroxy groups of D-glucaric acid were exposed in the hydrophilic channels, while the hydrophobic channels had $\mathrm{C}-\mathrm{H}$ bonds along the channel wall. Water molecules were in both channels, especially in the hydrophilic channel where they were hydrogen bonded. The water molecules in the hydrophobic channels were easily exchanged for azobenzene, $\mathrm{I}_{2}$, elemental sulfur, hydrocarbons, $\mathrm{CCl}_{4}$ and $\mathrm{CI}_{4}$. This material was expected to be applicable to the simultaneous introduction of two different species into the different channels.

Wong et al. synthesized a porous structure from meso-galactaric acid and terbium that could detect guest molecules (Figure 5) [46]. This structure formed a two-dimensional networked complex that created vertical one-dimensional channels when stacked in layers. Crystallography of this MOF revealed that the layers were connected through hydrogen bonding via water molecules; however, heating removed the water molecules without destroying the structure. In aqueous solutions, this MOF could remove $\mathrm{I}^{-}, \mathrm{Br}^{-}, \mathrm{Cl}^{-}, \mathrm{F}^{-}, \mathrm{CN}^{-}$, and $\mathrm{CO}_{3}{ }^{2-}$ and small amounts of $\mathrm{SO}_{4}{ }^{2-}$ and $\mathrm{PO}_{4}{ }^{3-}$. These anions were assumed to be removed by forming hydrogen bonds with the meso-galactaric acid moieties. The fluorescent properties of terbium, a lanthanide element, were successfully utilized to monitor the intake of anions into the MOF. Desorption of the anions from the MOF was confirmed by placing the absorbed complexes in pure water. 


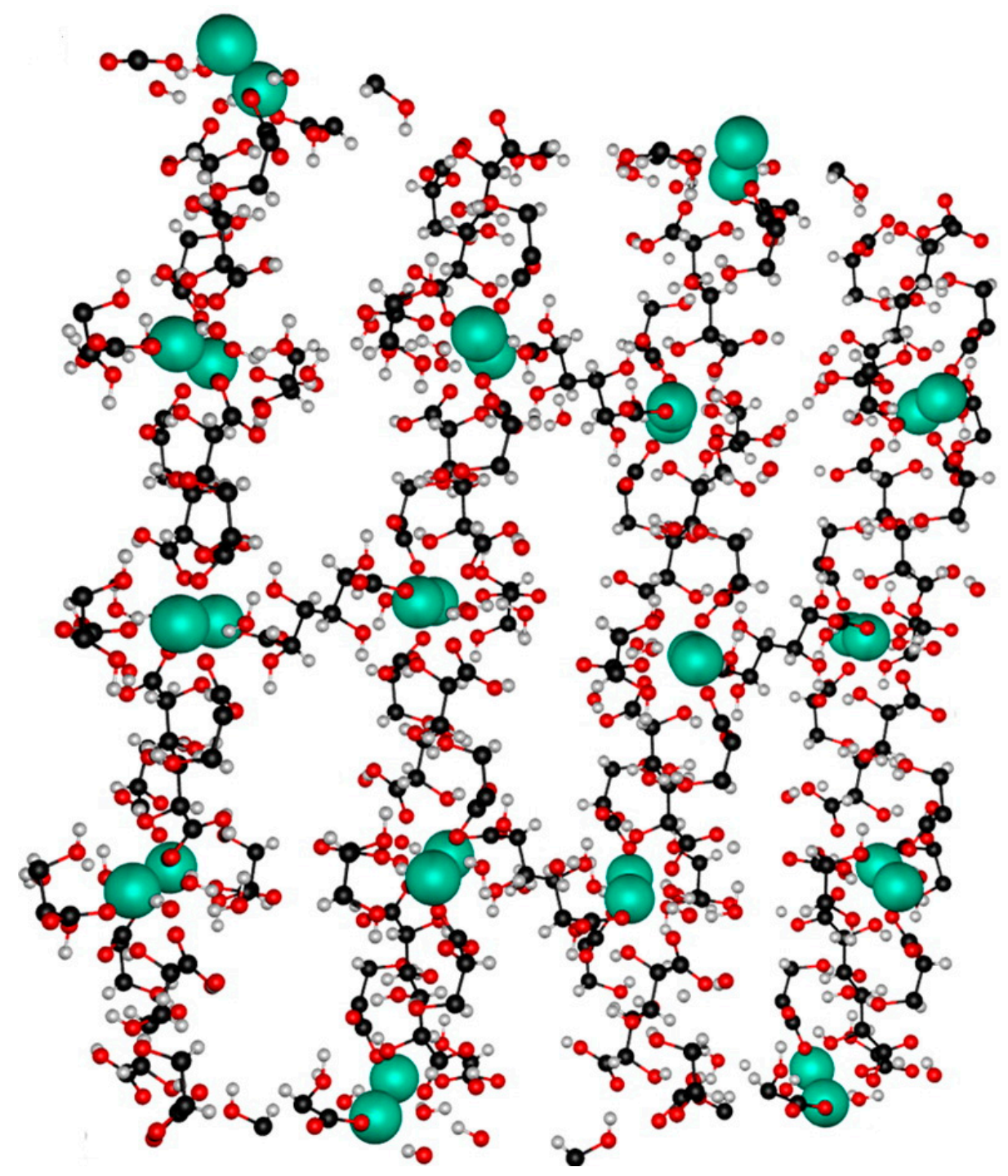

Figure 5. Crystal structure of the neutral metal-organic framework (MOF) $\left(\mathrm{Tb}\right.$ (galactarate) $\left.{ }_{1.5}\left(\mathrm{H}_{2} \mathrm{O}\right)_{2}\right) \cdot 5 \mathrm{H}_{2} \mathrm{O}$ shown in a ball-and-stick representation, with the $\mathrm{Tb}(\mathrm{III})$ ions in a space-filling model. Water molecules in the channels have been omitted for clarity, and atoms are color coded as follows: $\mathrm{C}=$ black; $\mathrm{H}=$ white; $\mathrm{O}=$ red; $\mathrm{Tb}=$ turquoise [48].

\subsection{Other Platform Chemicals}

Hexaric acids have also been studied for use as the starting materials for other platform chemicals [54-62], including adipic acid [59-62], furan dicarboxylic acid (an alternative to terephthalic acid) [57], and pyrrole [55].

Li et al. reported the highly efficient conversion of meso-galactaric acid, via muconic acid, into adipic acid through an oxorhenium-complex-catalyzed deoxydehydration (DODH) reaction and following a Pt/C-catalyzed transfer hydrogenation [59]. Ionic liquid was integrated as a reaction medium into this DODH reaction in another paper [61]. The use of ionic liquid enabled an efficient separation of muconic acid by simple decantation. The recovered ionic liquid, which contained an expensive Re catalyst, was used up to four times without much of a decrease in yields. D-Glucaric acid can also be a starting compound for adipic acid. Recently, a catalyst system that provided adipate esters from D-glucaric acid in a single operation was reported, in which hydrogen was used as a terminal reductant [62]. 
According to the report by Thiyagarajan et al. [58], although the first report of furan-2,5-dicarboxylic acid from meso-galactaric acid was published in 1876, little attention has been paid to this route because isolated yields were moderate and meso-galactaric acid was not readily available. In terms of the availability of hexaric acids including meso-galactaric acid, it will be improved by the research mentioned in following sections. As for synthesis of furan-2,5-dicarboxylic acid from meso-galactaric acid, some works were reported. For example, one-step synthesis of dibutyl furandicarboxylates from meso-galactaric acid and 1-butanol, in the presence of sulfuric acid, was reported [57]. In this paper, the diester of furan-2,5-dicarboxylic acid was synthesized because it can be distilled or recrystallized by the use of existing solvents and can be polymerized directly using diols.

\section{Hexaric Acid Production Using Inorganic Catalysts}

The earliest attempts of hexaric acid preparation were reported in the late 1800s (oxidation of carbohydrates with $\mathrm{HNO}_{3}$, of which the reaction origin could be traced back to lactose oxidation by Liebig and is still used today $[65,66])$. However, the yields using this method are limited to approximately $40 \%$ because of side reactions. Moreover, this method results in the excessive production of nitrogen oxide gas because of the rapid and highly exothermic nature of the oxidation reaction. These drawbacks have prevented the mass production of hexaric acids using this method $[67,68]$. Kiely's group have improved D-glucaric and D-mannaric acid production via nitric acid oxidation to solve these problems, enabling industrial mass production of these hexaric acids (Figure 6) [67,69].

(A)

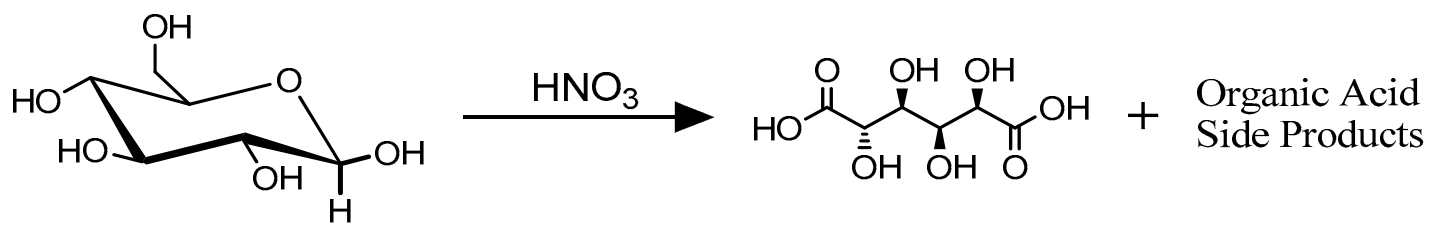

(B)

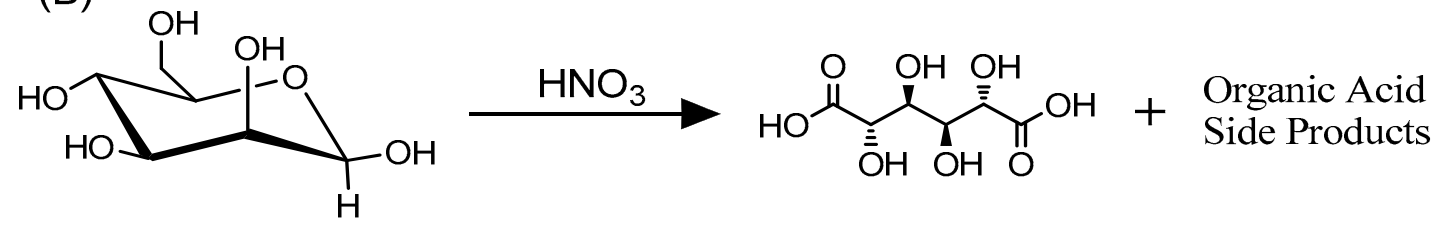

Figure 6. The nitric oxidation of (A) D-glucose and (B) D-mannose [67,69].

In their studies, the amount, rate, and temperature of the D-glucose and D-mannose additions were controlled by a computer to prevent rapid temperature increases caused by the oxidation of the saccharides by nitric acid and the resulting generation of large amounts of nitrogen dioxide and other gases. Relatively low reaction temperatures $\left(25-40{ }^{\circ} \mathrm{C}\right)$ were accomplished. Furthermore, a positive oxygen pressure on the reaction system generated nitric dioxide from nitric monoxide, and the dissolution of the dioxide into water reproduced nitric acid, enabling reproduction and recycling of the nitric acid (Figure 7). The removal of nitric acid from the reaction mixture was also improved.

$$
\begin{aligned}
& 2 \mathrm{NO}_{(\mathrm{g})}+\mathrm{O}_{2(\mathrm{~g})} \longrightarrow 2 \mathrm{NO}_{2(\mathrm{~g})} \\
& 2 \mathrm{NO}_{2(\mathrm{~g})}+\mathrm{H}_{2} \mathrm{O}_{(\mathrm{l})} \rightleftharpoons \mathrm{HNO}_{3(\mathrm{l})}+\mathrm{HNO}_{2(\mathrm{l})} \\
& 3 \mathrm{NO}_{2(\mathrm{~g})}+\mathrm{H}_{2} \mathrm{O}_{(\mathrm{l})} \rightleftharpoons \mathrm{HNO}_{3(\mathrm{l})}+\mathrm{NO}_{(\mathrm{g})} \\
& 3 \mathrm{HNO}_{3(\mathrm{l})} \longrightarrow \mathrm{HNO}_{3(\mathrm{l})}+2 \mathrm{NO}_{(\mathrm{g})}+\mathrm{H}_{2} \mathrm{O}_{(\mathrm{l})}
\end{aligned}
$$

Figure 7. Common $\mathrm{NO}$ and $\mathrm{NO}_{2}$ reactions in water/ $\mathrm{O}_{2}$ proposed in a previous report [69]. 
To date, nitric acid has been removed by evaporation by heating under reduced pressure. However, complete removal is difficult because nitric acid and water form a negative azeotrope. Moreover, the relatively severe conditions used in this method allow for further oxidation reactions to occur in an uncontrolled manner. Therefore, nitric acid removal by nanofiltration and diffusion dialysis was also investigated in Kiely's study. Selective nitric acid removal was achieved by both methods. However, because the addition of a large amount of water and $\mathrm{pH}$ adjustment was necessary, nanofiltration was not practical. Diffusion dialysis required neither the addition of water, the adjustment of $\mathrm{pH}$, nor large amounts of energy for nitric acid removal. Further recycling of the removed nitric acid was easy. However, a problem remains in that the removed nitric acid solution contains a large amount of the products. Moreover, the yield of the reaction was not improved, remaining at $45 \%$ for D-glucaric acid. In addition to nitric acid oxidation, the production of hexaric acids by oxidation with bromine and manganese(III) sulfate has been reported [70-73]. Recently, ozonic oxidation has been proposed to solve several of the problems of conventional conversions, including their high environmental burden, byproduct generation, slow reaction rates, and high costs [74,75].

In addition to the use of strong oxidants, catalytic oxidation with transition metals has been explored. The Pt-catalyzed production of a hexaric acid, D-mannaric acid, was reported in 1938 [76]. Production of hexaric acids catalyzed by metals has been of industrial interest since the 1940s [77-81]. Following these antecedent works, several studies have been reported [68,82-98]. Although Pt [76,82-84,91,92,97] and Au [68,84-86,89,94-96] have been used as catalysts frequently, other elements like Ti [87,88], Mn [90], Fe [98], Mo [93], and Pd [91,99] can also be incorporated in catalyst composites. Aldohexoses [84-88,90-95,97,98], aldohexonic acids [82-84], and hexuronic acid $[68,89,96]$, in addition to the corresponding sugar alcohol $[76,85]$, can be starting compounds for the metal-catalyzed production of hexaric acids. In addition to the use of oxidants like $\mathrm{H}_{2} \mathrm{O}_{2}$ and $\mathrm{O}_{2}$, electrochemical $[85,90]$ and photochemical $[87,88]$ oxidation of the substrates has been examined. Recently, catalysis under autogenous $\mathrm{pH}$ conditions has attracted attention, although alkaline conditions were favored for some traditional efficient catalysis reactions [95-97].

Hexaric acid separation from the reaction mixture was based on various methodologies, including precipitation by lowering the $\mathrm{pH}$ and the use of ion exchange resins $[67,69,100]$. For example, D-glucarate was isolated by $\mathrm{pH}$ change (basification of the reaction mixture to $\mathrm{pH} 9.5$, which was followed by acidification to $\mathrm{pH} 3-4$ [67]). meso-Galactarate was also separated from the culture supernatant by acid precipitation, where $97 \%$ recovery was achieved with $97.5 \%$ purity at $\mathrm{pH} 6.5$ [100]. D-Glucarate and D-mannarate were separated from each reaction mixture by ion exchange resins following their analyses $[67,69]$.

\section{Hexaric Acid Production Using Biocatalysts}

Hexaric acid production using biocatalysts has also been studied. Biocatalysts, which are regenerable, enable environmentally friendly hexaric acid production. Furthermore, the substrate and reaction specificity of biocatalysts commonly omit the need for strict purification processes to extract the saccharides from the biomass [6].

Although a variety of dehydrogenases and oxidases are known to oxidize hexoses at the $\mathrm{C} 1$ position, few reports describe direct enzymatic oxidation of hexoses at the $\mathrm{C} 6$ position, such as eukaryotic and bacterial organisms that use uridine diphosphate (UDP)- and guanosine diphosphate (GDP)-bound hexoses as substrates to oxidize the C6 position. The products of these reactions are UDP- and GDP-uronic acids, which serve as the starting compounds for synthesizing polysaccharides, ascorbic acid, and other biomolecules [6,101-105].

Because direct oxidation of hexose at the $\mathrm{C} 6$ position is difficult, combinations of biocatalysts have been used to produce hexuronic acids. For instance, Moon et al. reported a method for the production of D-glucaric acid using genetically modified Escherichia coli (E. coli, Figure 8) [106]. In recombinant $E$. coli, phosphotransferase activity produces D-glucose-6-phosphate, which is then converted by myo-inositol-1-phosphate synthase into myo-inositol-1-phosphate. A phosphatase then 
converts the myo-inositol-1-phosphate into myo-inositol, which is then converted to D-glucuronic acid (the hexuronic acid of D-glucose) by myo-inositol oxidase. Moon's report also describes the production of D-glucaric acid from the oxidation of D-glucuronic acid by nicotinamide adenine dinucleotide (NAD)-dependent uronate dehydrogenase (UDH). Because the yield of this reaction was low, improvements in the production system have been made [107-112]. Galactose oxidase is an uncommon enzyme that can oxidize hexoses at the C6 position. For example, D-galactose oxidation catalyzed by this enzyme produces D-galactohexodialdose $[113,114]$. The enzymatic oxidation of D-galactohexodialdose cannot produce hexuronic acid or hexaric acid because bicyclic structures are formed; however, the oxidation of dialdose by sodium chlorite is reported to produce D-galacturonic acid, the hexuronic acid of D-galactose [115]. Recently, a mutation in this enzyme, changing its structure, was reported to enable glucose oxidation at the C6 position $[107,116,117]$.<smiles>OC[C@H]1OC(O)[C@H](O)[C@@H](O)[C@@H]1O</smiles>

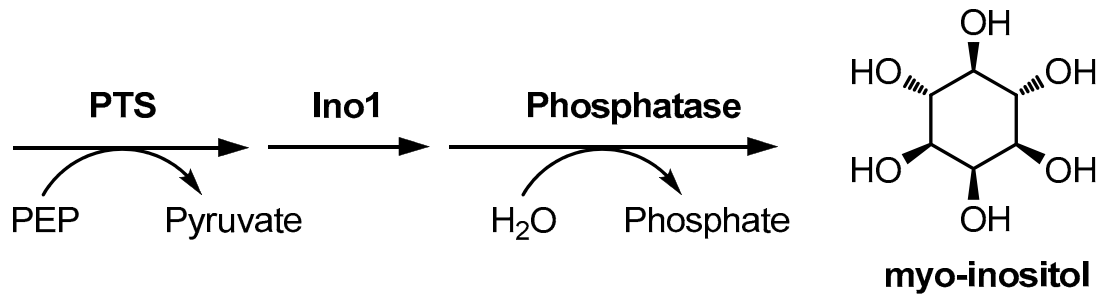

D-glucose

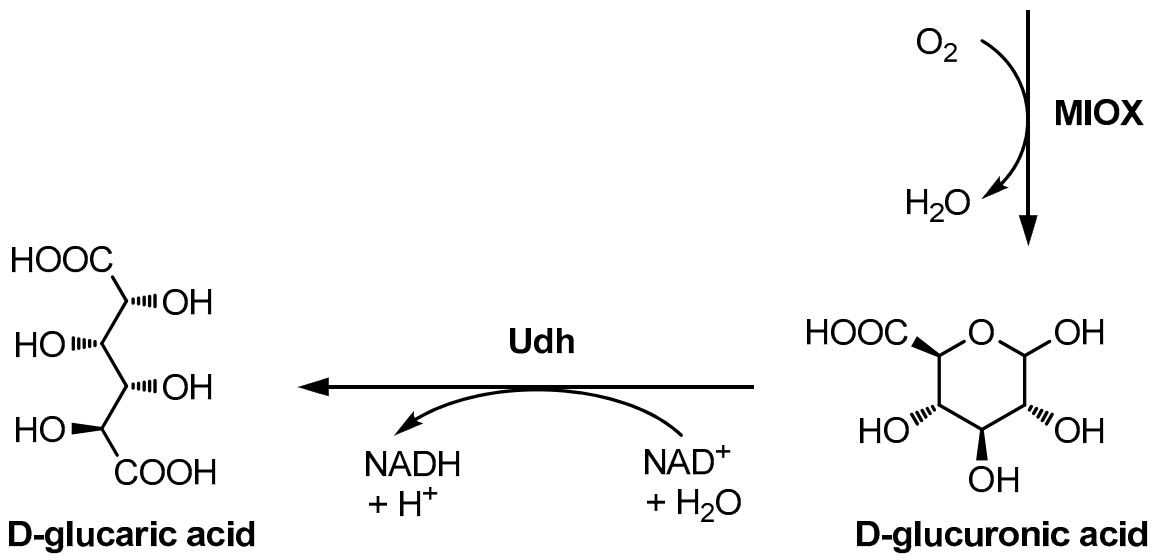

Figure 8. Designed pathway for the production of D-glucaric acid in E. coli. PTS = phosphoenolpyruvate -dependent phosphotransferase system; phosphatase $=\mathrm{SuhB}$, an endogenous E. coli enzyme; $\mathrm{PEP}=$ phosphoenolpyruvate; $\mathrm{MIOX}=$ myo-inositol oxygenase; $\mathrm{Udh}=$ uronate dehydrogenase; [106].

As described above, UDP- and GDP-uronic acids have been utilized to synthesize polysaccharides in vivo; thus, hexuronic acids are abundant in nature as the main component of polysaccharides [6,101-105]. For example, D-galacturonic acid can be derived from pectin [118-121]. Alginic acid hydrolysis produces D-mannuronic acid and L-guluronic acid, the hexuronic acids of D-mannose and L-gulose, respectively [122-127]. D-Glucuronic acid can be obtained from hemicellulose [128,129]. D-Glucuronic acid can also be obtained as a monomer from ulvan $[123,130]$. Therefore, some studies have used hexuronic acids derived from polysaccharides, which are not used as food, as the starting compounds for hexaric acids.

Mojzita et al. reported the production of meso-galactaric acid from D-galacturonic acid using recombinant microorganisms in which the gene for UDH had been introduced [100]. Many microorganisms that live on putrid plants have enzymatic pathways that catabolize D-galacturonic acid. Eukaryotic microorganisms use a reduction pathway that starts with the reduction of D-galacturonic acid into L-galactonic acid, catalyzed by D-galacturonic acid reductase, while bacteria use an oxidative pathway that first produces meso-galactaric acid in a reaction catalyzed by UDH. In their study, Mojzita et al. eliminated the gene for D-galacturonic acid reductase in two eukaryotic microorganisms, Aspergillus niger (A. niger) and Hypocrea jecorina (H. jecorina), and introduced the gene for UDH, which was derived from 
the bacterium Agrobacterium tumefaciens (A. tumefaciens). Neither strain with a single-gene deletion of the reductase grew on medium in which D-galacturonic acid was the sole carbon source. In contrast, meso-galactaric acid production in both strains was confirmed when deletion of the reductase was accompanied by introduction of the dehydrogenase (Figure 9). Because the amount of meso-galactaric acid obtained was small in the case of $A$. niger, it is assumed that $A$. niger metabolizes meso-galactaric acid derived from D-galacturonic acid. Although a high yield of meso-galactaric acid was achieved with $H$. jecorina, the addition of D-glucose as an energy source was necessary because D-galacturonic acid cannot be used as the sole carbon source. Furthermore, the addition of D-glucose was found to decrease the yield of meso-galactaric acid. The fermentation method used to produce meso-galactaric acid has been improved [131-136].<smiles>O=C([O-])C(O)C(O)C(O)C(O)CO</smiles>

L-Galactonate
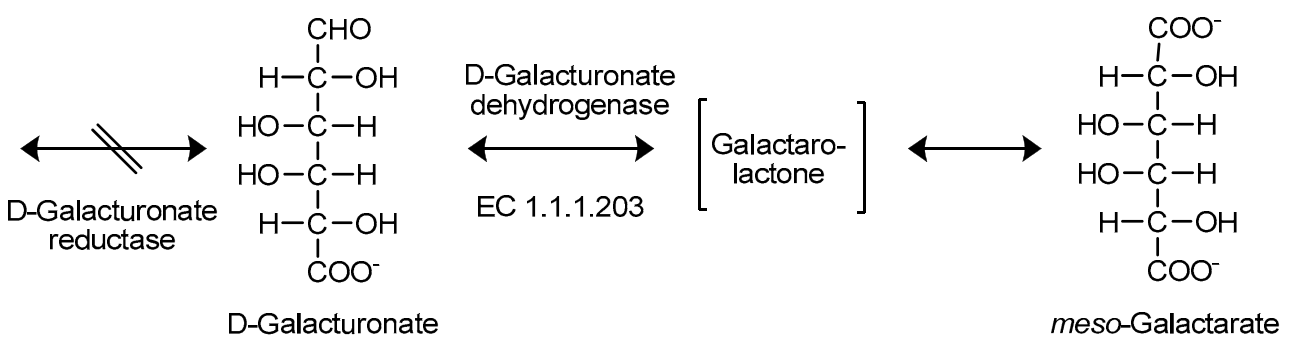

Figure 9. Engineering of the D-galacturonic acid pathway in fungi. Deletion of the gene encoding D-galacturonate reductase resulted in strains unable to utilize D-galacturonic acid as a carbon source. The expression of the bacterial $u d h$ gene, encoding an nicotinamide adenine dinucleotide (NAD)-dependent UDH (D-galacturonic acid dehydrogenase), resulted in fungal strains that were able to oxidize D-galacturonic acid to meso-galactaric acid. UDH forms a galactaro-lactone that spontaneously hydrolyzes [100].

When chemicals are produced through an oxidative reaction, the electrons obtained from the substrate are usually transferred to electron accepters, such as $\mathrm{O}_{2}$. However, an enzymatic anode in a biofuel cell can serve as an electron acceptor. Enzymatic oxidative conversion on the anode can be combined with $\mathrm{O}_{2}$ reduction on the cathode to generate electricity. That is, the simultaneous production of chemicals and electricity is possible through oxidative conversion within enzymatic biofuel cells. This method reduces the energy required for producing chemicals and can even generate energy for other uses. The concept of a system that co-produces platform chemicals and electrical energy from biomass by demonstrating the simultaneous production of a hexaric acid and electrical energy using an enzymatic biofuel cell has been proposed [137-139]. The electrochemical oxidation of D-galacturonic acid and the production of meso-galactaric acid by a pyrroloquinoline quinone-dependent glucose dehydrogenase (PQQ-GDH)-modified electrode was confirmed [137,139]. The electrode was used as the anode in a biofuel cell with a bilirubin oxidase (BOD) cathode [139] (Figure 10). The cell generated electricity by using D-galacturonic acid and the hydrolysate of pectic acid as a fuel. This simultaneous production mechanism is applicable to other chemicals. We confirmed the oxidation of D-glucuronate and D-mannuronate, both catalyzed by PQQ-GDH, and the oxidation of L-guluronate, catalyzed by the PQQ domain of pyranose dehydrogenase from Coprinopsis cinerea $\left(\mathrm{DH}_{\mathrm{PDH}}\right)[138,139]$. According to NMR measurements, the production of D-glucarate from the oxidation of D-glucuronate and L-guluronate and the production of $\mathrm{D}$-mannarate from the $\mathrm{D}$-mannuronate oxidation were confirmed. $\mathrm{DH}_{\mathrm{PDH}}$ is also suitable for use as an anode catalyst. These combinations of enzymes and chemicals are applicable to simultaneous production systems. 


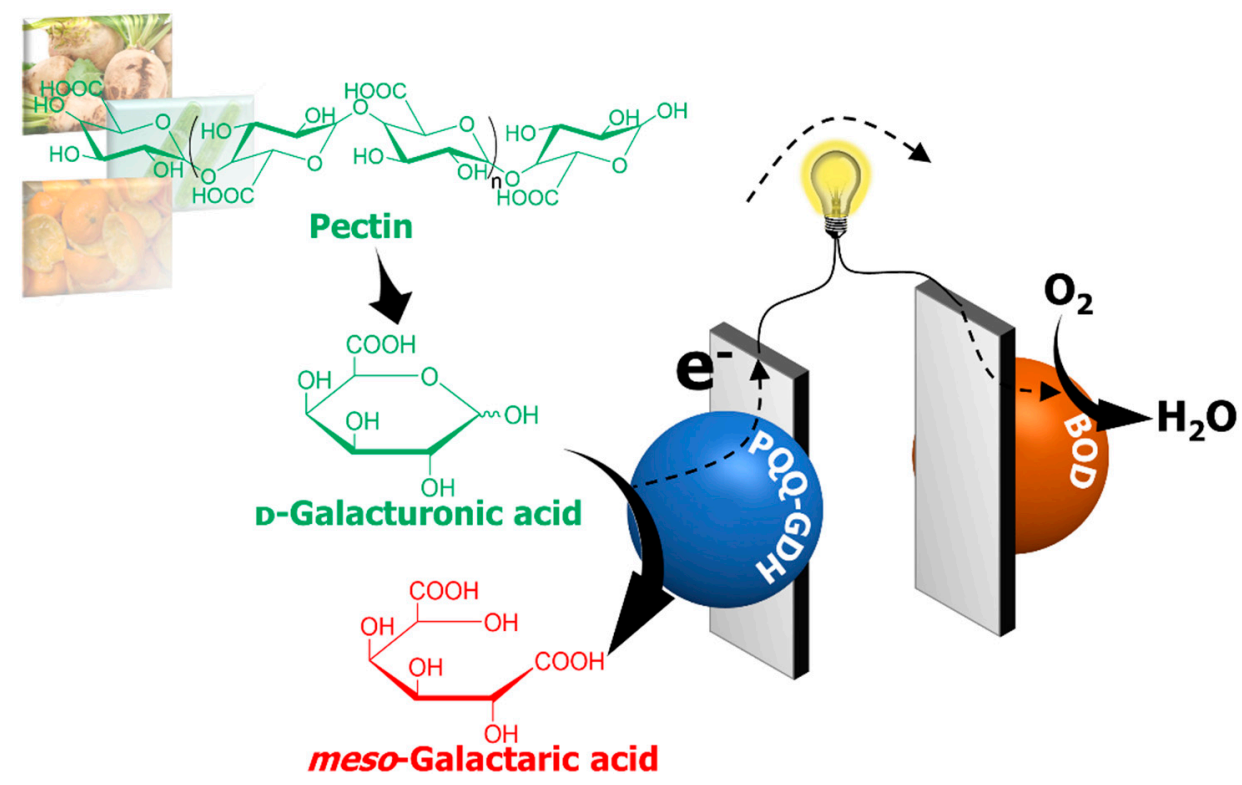

Figure 10. Schematic description of an enzymatic biofuel cell that simultaneously produces meso-galactaric acid and electricity from pectin extracted from biomass. PQQ-GHD = pyrroloquinoline quinone-dependent glucose dehydrogenase; $\mathrm{BOD}=$ bilirubin oxidase.

\section{Conclusions}

Hexaric acids are sugar acids that can be produced from biomass. Due to their stereochemical diversity, chelation abilities, and high solubility in water, numerous applications have been developed. These applications include their use as chelating agents and corrosion inhibitors and as precursors for various polymers, coordination polymers, macromolecules, cross-linkers in hydrogels, and medicines. The conventional production of hexaric acids is conducted by the oxidation of saccharides with nitric acids. To overcome the problems derived from the use of nitric acids, in addition to improving the nitric acid oxidation process, green chemical methods have been developed to produce hexaric acids. Transition metal catalysts and modified microorganisms have been utilized to produce hexaric acids from hexuronic acids under mild conditions. Quite recently, the production of hexuronic acids using high-frequency ultrasound irradiation without a catalyst has been reported [140]. In addition, the production of hexuronic acids by using metal catalysts has been developed [141]. Combining these technologies with the aforementioned technologies, the production of hexaric acids can be improved. Furthermore, hexaric acid was produced directly from aldohexoses by using modified microorganisms. The oxidation reaction of aldohexoses using enzymes is considered to have an advantage in terms of stereoselectivity. In the future, processes for producing hexaric acids using a biocatalyst including enzymes could be constructed.

Author Contributions: R.S. and N.N. wrote and edited the manuscript.

Funding: This research was partially funded by a Grant-in-Aid for JSPS Fellows (Grant No. 16J07225 to R.S.).

Conflicts of Interest: The authors declare no conflict of interest.

\section{Abbreviations}

$\begin{array}{ll}\text { DOE } & \text { The US Department of Energy } \\ \text { PEIs } & \text { Polyethylene imines } \\ \text { MOF } & \text { Metal-organic framework } \\ \text { UDP } & \text { Uridine diphosphate } \\ \text { GDP } & \text { Guanosine diphosphate }\end{array}$


UDH Uronate dehydrogenase

PQQ Pyrroloquinolone quinone

GDH Glucose dehydrogenase

BOD Bilirubin oxidase

$\mathrm{DH}_{\mathrm{PDH}} \mathrm{PQQ}$ domain of pyranose dehydrogenase from Coprinopsis cinerea

\section{References}

1. Cherubini, F. The biorefinery concept: Using biomass instead of oil for producing energy and chemicals. Energy Convers. Manag. 2010, 51, 1412-1421. [CrossRef]

2. de Jong, E.; Higson, A.; Walsh, P.; Wellisch, M. Product developments in the bio-based chemicals arena. Biofuels Bioprod. Biorefin. 2012, 6, 606-624. [CrossRef]

3. Werpy, T.; Peterson, G. Top Value Added Chemicals from Biomass: Volume I-Results of Screening for Potential Candidates from Sugars and Synthesis Gas; Technical Report Produced for the U.S. Department of Energy by the National Renewable Energy Laboratory: Washington, DC, USA, 2004.

4. Climent, M.J.; Corma, A.; Iborra, S. Converting carbohydrates to bulk chemicals and fine chemicals over heterogeneous catalysts. Green Chem. 2011, 13, 520-540. [CrossRef]

5. Isikgor, F.H.; Becer, C.R. Lignocellulosic biomass: A sustainable platform for the production of bio-based chemicals and polymers. Polym. Chem. 2015, 6, 4497-4559. [CrossRef]

6. Mehtiö, T.; Toivari, M.; Wiebe, M.G.; Harlin, A.; Penttilä, M.; Koivula, A. Production and applications of carbohydrate-derived sugar acids as generic biobased chemicals. Crit. Rev. Biotechnol. 2016, 36, 904-916. [CrossRef]

7. de Lederkremer, R.M.; Marino, C. Acids and their products of oxidation of sugars. Adv. Carbohydr. Chem. Biochem. 2003, 58, 199-306.

8. Alterman, M.; Björsne, M.; Mühlman, A.; Classon, B.; Kvarnström, I.; Danielson, H.; Markgren, P.-O.; Nillroth, U.; Unge, T.; Hallberg, A.; et al. Design and synthesis of new potent C2-symmetric HIV-1 protease inhibitors. Use of L-mannaric acid as a peptidomimetic scaffold. J. Med. Chem. 1998, 41, 3782-3792. [CrossRef]

9. Wachtmeister, J.; Mühlman, A.; Classon, B.; Kvarnström, I.; Hallberg, A.; Samuelsson, B. Impact of the central hydroxyl groups on the activity of symmetrical HIV-1 protease inhibitors derived from L-mannaric acid. Tetrahedron 2000, 56, 3219-3225. [CrossRef]

10. Chakraborty, T.K.; Ghosh, S.; Jayaprakash, S.; Sharma, J.A.R.P.; Ravikanth, V.; Diwan, P.V.; Nagaraj, R.; Kunwar, A.C. Synthesis and conformational studies of peptidomimetics containing furanoid sugar amino acids and a sugar diacid. J. Org. Chem. 2000, 65, 6441-6457. [CrossRef]

11. Chakraborty, T.K.; Ghosh, S.; Rao, M.H.V.R.; Kunwar, A.C.; Cho, H.; Ghosh, A.K. 2, 5-Anhydro sugar diacid and 2,5-anhydro sugar diamine based $C 2$ symmetric peptidomimetics as potential HIV-1 protease inhibitors. Tetrahedron Lett. 2000, 41, 10121-10125. [CrossRef]

12. Mehltretter, C.L.; Alexander, B.H.; Rist, C.E. Sequestration by sugar acids. Ind. Eng. Chem. 1953, 45, 2782-2784. [CrossRef]

13. Gónzalez-Portal, A.; Baluja-Santos, C.; Bermejo-Mártinez, F. Spectrophotometric determination of bismuth in pharmaceutical preparations using mucic acid. Analyst 1986, 111, 547-549. [CrossRef] [PubMed]

14. Ramos, M.L.; Caldeira, M.M.; Gil, V.M.S. Multinuclear NMR study of the complexation of D-glucaric acid with molybdenum(VI) and tungsten(VI). Inorg. Chim. Acta 1991, 180, 219-224. [CrossRef]

15. Ramos, M.L.; Caldeira, M.M.; Gil, V.M.S.; van Bekkum, H.; Peters, J.A. Multinuclear NMR study of the complexation of D-galactaric and D-mannaric acids with molybdenum(VI). Polyhedron 1994, 13, 1825-1833. [CrossRef]

16. Ramos, M.L.; Caldeira, M.M.; Gil, V.M.S.; van Bekkum, H.; Peters, J.A. Multinuclear NMR study of complexation of D-galactaric and D-mannaric acids with tungsten(VI) oxoions. J. Coord. Chem. 1994, 33, 319-329. [CrossRef]

17. Abbadi, A.; Gotlieb, K.F.; Meiberg, J.B.M.; Peters, J.A.; van Bekkum, H. New Ca-sequestering materials. Based on the oxidation of the hydrolysis products of lactose. Green Chem. 1999, 1, 231-235. [CrossRef]

18. Saladini, M.; Ferrari, E.; Menabue, L. Co-ordination of transition metal ions by galactaric acid: A potentiometric and spectroscopic study. J. Inorg. Biochem. 2002, 92, 121-127. [CrossRef] 
19. Lakatos, A.; Bertani, R.; Kiss, T.; Venzo, A.; Casarin, M.; Benetollo, F.; Ganis, P.; Favretto, D. AlIII ion complexes of saccharic acid and mucic acid: A solution and solid-state study. Chem. Eur. J. 2004, 10, 1281-1290. [CrossRef]

20. Abrahams, B.F.; McCormick, L.J.; Moubaraki, B.; Murray, K.S.; Robson, R.; Waters, T. Two Cu21 clusters with pseudo- $D_{3}$ symmetry derived from the D-saccharate pentaanion, $\mathrm{C}_{6} \mathrm{H}_{5} \mathrm{O}_{8}{ }^{5-}$. Chem. Eur. J. 2011, 17, 7454-7459. [CrossRef]

21. Koefod, R.S. Corrosion-inhibiting deicer composition. U.S. Patent 7658861B2, 9 February 2010.

22. Wolfrom, M.L.; Toy, M.S.; Chaney, A. Condensation polymers from tetra-o-acetylgalactaroyl dichloride and diamines. J. Am. Chem. Soc. 1958, 80, 6328-6330. [CrossRef]

23. Bird, T.P.; Black, W.A.P.; Dewar, E.T.; Hare, J.B. Polyamides containing carbohydrate residues. J. Chem. Soc. 1963, 1208-1212. [CrossRef]

24. Bird, T.P.; Black, W.A.P.; Dewar, E.T.; Hare, J.B. Polyamides containing carbohydrate residues. Part II. Benzylidenedioxy-derivatives. J. Chem. Soc. 1963, 3389-3391. [CrossRef]

25. Ogata, N.; Sanui, K.; Hosoda, Y.; Nakamura, H. Active polycondensation of diethyl 2, 3, 4, 5-tetrahydroxyadipate with diamines. J. Polym. Sci. Polym. Chem. Ed. 1976, 14, 783-792. [CrossRef]

26. Ogata, N.; Sanui, K.; Kayama, Y. Copolycondensation of hydroxyl diesters and active diesters with hexamethylenediamine. J. Polym. Sci. Polym. Chem. Ed. 1977, 15, 1523-1526. [CrossRef]

27. Ogata, N.; Sanui, K.; Hosoda, Y.; Nakamura, H.; Kishi, H. Polycondensation of diethyl mucate with hexamethylenediamine in the presence of poly(vinyl pyridine). J. Polym. Sci. Polym. Chem. Ed. 1980, 18, 933-938. [CrossRef]

28. Kiely, D.E.; Chen, L.; Lin, T.-H. Hydroxylated nylons based on unprotected esterified D-glucaric acid by simple condensation reactions. J. Am. Chem. Soc. 1994, 116, 571-578. [CrossRef]

29. Chen, L.; Kiely, D.E. Synthesis of stereoregular head, tail hydroxylated nylons derived from D-glucose. J. Org. Chem. 1996, 61, 5847-5851. [CrossRef]

30. Morton, D.W.; Kiely, D.E. Evaluation of the film and adhesive properties of some block copolymer polyhydroxypolyamides from esterified aldaric acids and diamines. J. Appl. Polym. Sci. 2000, 77, 3085-3092. [CrossRef]

31. Kiely, D.E.; Chen, L.; Lin, T.-H. Synthetic polyhydroxypolyamides from galactaric, xylaric, D-glucaric, and D-mannaric acids and alkylenediamine monomers-Some comparisons. J. Polym. Sci. A Polym. Chem. 2000, 38, 594-603. [CrossRef]

32. Orgueira, H.A.; Varela, O. Synthesis and characterization of stereoregular AABB-type polymannaramides. J. Polym. Sci. A Polym. Chem. 2001, 39, 1024-1030. [CrossRef]

33. Mancera, M.; Roffé, I.; Rivas, M.; Galbis, J.A. New derivatives of D-mannaric and galactaric acids: Synthesis of a new stereoregular Nylon 66 analog from carbohydrate-based monomers having the D-manno configuration. Carbohydr. Res. 2003, 338, 1115-1119. [CrossRef]

34. Henkensmeier, D.; Abele, B.C.; Candussio, A.; Thiem, J. Synthesis, characterisation and degradability of polyamides derived from aldaric acids and chain end functionalised polydimethylsiloxanes. Polymer 2004, 45, 7053-7059. [CrossRef]

35. Liu, Y.; Reineke, T.M. Hydroxyl stereochemistry and amine number within poly(glycoamidoamine)s affect intracellular DNA delivery. J. Am. Chem. Soc. 2005, 127, 3004-3015. [CrossRef] [PubMed]

36. Muñoz-Guerra, S. Carbohydrate-based polyamides and polyesters: An overview illustrated with two selected examples. High Perform. Polym. 2012, 24, 9-23. [CrossRef]

37. Black, W.A.P.; Dewar, E.T.; Hare, J.B. Polyesters containing carbohydrate residues. J. Chem. Soc. 1963, 5724-5727. [CrossRef]

38. Zamora, F.; Hakkou, K.; Alla, A.; Rivas, M.; de Ilarduya, A.M.; Muñoz-Guerra, S.; Galbis, J.A. Butylene copolyesters based on aldaric and terephthalic acids. Synthesis and characterization. J. Polym. Sci. Part A Polym. Chem. 2009, 47, 1168-1177. [CrossRef]

39. Lavilla, C.; Alla, A.; de Ilarduya, A.M.; Benito, E.; García-Martín, M.G.; Galbis, J.A.; Muñoz-Guerra, S. Carbohydrate-based polyesters made from bicyclic acetalized galactaric acid. Biomacromolecules 2011, 12, 2642-2652. [CrossRef]

40. Lavilla, C.; Alla, A.; de Ilarduya, A.M.; Benito, E.; García-Martín, M.G.; Galbis, J.A.; Muñoz-Guerra, S. Bio-based poly(butylene terephthalate) copolyesters containing bicyclic diacetalized galactitol and galactaric acid: Influence of composition on properties. Polymer 2012, 53, 3432-3445. [CrossRef] 
41. Lavilla, C.; Alla, A.; de Ilarduya, A.M.; Benito, E.; García-Martín, M.G.; Galbis, J.A.; Muñoz-Guerra, S. Carbohydrate-based copolyesters made from bicyclic acetalized galactaric acid. J. Polym. Sci. Part A Polym. Chem. 2012, 50, 1591-1604. [CrossRef]

42. Mehtiö, T.; Nurmi, L.; Rämö, V.; Mikkonen, H.; Harlin, A. Synthesis and characterization of copolyanhydrides of carbohydrate-based galactaric acid and adipic acid. Carbohydr. Res. 2015, 402, 102-110. [CrossRef]

43. Pan, D.W.; Davis, M.E. Cationic mucic acid polymer-based siRNA delivery systems. Bioconjug. Chem. 2015, 26, 1791-1803. [CrossRef]

44. Abrahams, B.F.; Moylan, M.; Orchard, S.D.; Robson, R. Zinc Saccharate: A Robust, 3D coordination network with two types of isolated, parallel channels, one hydrophilic and the other hydrophobic. Angew. Chem. Int. Ed. 2003, 42, 1848-1851. [CrossRef]

45. Abrahams, B.F.; Moylan, M.; Orchard, S.D.; Robson, R. Channel-containing lanthanide mucate structures. CrystEngComm 2003, 5, 313-317. [CrossRef]

46. Wong, K.-L.; Law, G.-L.; Yang, Y.-Y.; Wong, W.-T. A highly porous luminescent terbium-organic framework for reversible anion sensing. Adv. Mater. 2006, 18, 1051-1054. [CrossRef]

47. Abrahams, B.F.; Grannas, M.J.; McCormick, L.J.; Robson, R.; Thistlethwaite, P.J. Chiral and achiral linear coordination polymers from aldaric acids. CrystEngComm 2010, 12, 2885-2895. [CrossRef]

48. Busschaert, N.; Caltagirone, C.; van Rossom, W.; Gale, P.A. Applications of Supramolecular Anion Recognition. Chem. Rev. 2015, 115, 8038-8155. [CrossRef] [PubMed]

49. Kawaguchi, A.W.; Okawa, H.; Hashimoto, K. Synthesis of glycopolymers bearing mannaric pendants as inhibitors on the $\beta$-glucuronidase activity: The inhibition mechanisms of mannaric-and glucaric-compounds. J. Polym. Sci. Part A Polym. Chem. 2009, 47, 2032-2042. [CrossRef]

50. Tian, L.; Yam, L.; Zhou, N.; Tat, H.; Uhrich, K.E. Amphiphilic Scorpion-like Macromolecules: Design, Synthesis, and Characterization. Macromolecules 2004, 37, 538-543. [CrossRef]

51. Gu, L.; Faig, A.; Abdelhamid, D.; Uhrich, K. Sugar-based amphiphilic polymers for biomedical applications: From nanocarriers to therapeutics. Acc. Chem. Res. 2014, 47, 2867-2877. [CrossRef]

52. Pohjanlehto, H.; Setälä, H.; Kammiovirta, K.; Harlin, A. The use of N, N'-diallylaldardiamides as cross-linkers in xylan derivatives-based hydrogels. Carbohydr. Res. 2011, 346, 2736-2745. [CrossRef]

53. Calcium-D-Glucarate. Available online: https://www.ncbi.nlm.nih.gov/pubmed/12197785 (accessed on 25 July 2019).

54. Butler, C.L.; Cretcher, L.H. The preparation of allomucic acid and certain of its derivatives. J. Am. Chem. Soc. 1929, 51, 2167-2170. [CrossRef]

55. Williams, S.R.; Maynard, H.D.; Chmelka, B.F. Synthesis of ${ }^{13}$ C-enriched pyrrole from $2-{ }^{13}$ C D-galactose. J. Label. Compd. Radiopharm. 1999, 42, 927-936. [CrossRef]

56. Pellissier, H. Syntheses of 1-induronyl synthons. A review. Org. Prep. Proced. Int. 2002, 34, 441-465. [CrossRef]

57. Taguchi, Y.; Oishi, A.; Iida, H. One-step synthesis of dibutyl furandicarboxylates from galactaric acid. Chem. Lett. 2008, 37, 50-51. [CrossRef]

58. Thiyagarajan, S.; Pukin, A.; van Haveren, J.; Lutz, M.; van Es, D.S. Concurrent formation of furan-2, 5-and furan-2, 4-dicarboxylic acid: Unexpected aspects of the Henkel reaction. RSC Adv. 2013, 3, 15678-15686. [CrossRef]

59. Li, X.; Wu, D.; Lu, T.; Yi, G.; Su, H.; Zhang, Y. Highly efficient chemical process to convert mucic acid into adipic acid and DFT studies of the mechanism of the rhenium-catalyzed deoxydehydration. Angew. Chem. Int. Ed. 2014, 53, 4200-4204. [CrossRef] [PubMed]

60. Zhang, H.; Li, X.; Su, X.; Ang, E.L.; Zhang, Y.; Zhao, H. Production of adipic acid from sugar beet residue by combined biological and chemical catalysis. ChemCatChem 2016, 8, 1500-1506. [CrossRef]

61. Shin, N.; Kwon, S.; Moon, S.; Hong, C.H.; Kim, Y.G. Ionic liquid-mediated deoxydehydration reactions: Green synthetic process for bio-based adipic acid. Tetrahedron 2017, 73, 4758-4765. [CrossRef]

62. Larson, R.T.; Samant, A.; Chen, J.; Lee, W.; Bohn, M.A.; Ohlmann, D.M.; Zuend, S.J.; Toste, F.D. Hydrogen gas-mediated deoxydehydration/hydrogenation of sugar acids: Catalytic conversion of glucarates to adipates. J. Am. Chem. Soc. 2017, 139, 14001-14004. [CrossRef]

63. Jeffery, G.A.; Wood, R.A. The crystal structure of galactaric acid (mucic acid) at $-147^{\circ}$ : An unusually dense, hydrogen-bonded structure. Carbohydr. Res. 1982, 108, 205-211. [CrossRef] 
64. Taga, T.; Kuroda, Y.; Osaki, K. Interactions of calcium ions with carbohydrates: X-ray diffraction and NMR spectroscopic studies on the potassium salt and the calcium salt of D-glucaric acid. Bull. Chem. Soc. Jpn. 1977, 50, 3079-3083. [CrossRef]

65. Sohst, O.; Tollens, B. Über krystallisirte Zuckersäure (Zuckerlactonsäure). Justus Liebig's Ann. Chem. 1888, 245, 1-27. [CrossRef]

66. Easterfield, T.H. XXXIV.-The oxidation of mannitol by nitric acid. d.-Mannosaccharic acid. J. Chem. Soc. Trans. 1891, 59, 306-310. [CrossRef]

67. Smith, T.N.; Hash, K.; Davey, C.-L.; Mills, H.; Williams, H.; Kiely, D.E. Modifications in the nitric acid oxidation of D-glucose. Carbohydr. Res. 2012, 350, 6-13. [CrossRef] [PubMed]

68. Rautiainen, S.; Lehtinen, P.; Chen, J.; Leskelä, M.; Niemelä, K.; Leskelä, M.; Repo, T. Selective oxidation of uronic acids into aldaric acids over gold catalyst. RSC Adv. 2015, 5, 19502-19507. [CrossRef]

69. Carpenter, C.A.; Hardcastle, K.I.; Kiely, D.E. Modifications in the nitric acid oxidation of D-mannose: X-ray crystal structure of N, N'-dimethyl D-mannaramide. Carbohydr. Res. 2013, 376, 29-36. [CrossRef] [PubMed]

70. Fauvarque, J.-F.; Mestre, M.; Trévin, S.; Marzouk, H.; Jud, J.-M. Recent industrial experiences with electroorganic synthesis-industrial electrosynthesis of an insoluble compound-galactaric acid. Actual. Chim. 1998, 214, 48-50.

71. Rangappa, K.S.; Anitha, N.; Nikath, M.A.; Rai, K.M.L.; Gowda, N.M.M. Oxidation of uronic acids by manganese(III) sulfate in acid solution: A kinetic and mechanistic study. Synth. React. Inorg. Met. Org. Chem. 2001, 31, 713-723. [CrossRef]

72. Merbouh, N.; Bobbitt, J.M.; Brückner, C. 4-AcNH-tempo-catalyzed oxidation of aldoses to aldaric acids using chlorine or bromine as terminal oxidants. J. Carbohydr. Chem. 2002, 21, 65-77. [CrossRef]

73. Ibert, M.; Marsais, F.; Merbouh, N.; Brückner, C. Determination of the side-products formed during the nitroxide-mediated bleach oxidation of glucose to glucaric acid. Carbohydr. Res. 2002, 337, 1059-1063. [CrossRef]

74. Marcq, O.; Barbe, J.-M.; Trichet, A.; Guilard, R. Reaction pathways of glucose oxidation by ozone under acidic conditions. Carbohydr. Res. 2009, 344, 1303-1310. [CrossRef] [PubMed]

75. Bonhoure, J.-P.; Abboud, H.; Aussenac, T.R.; Coste, C.U.; Hoang, L.; Ralainirina, R.; Rannou, A.C. New method for synthesising mucic acid using ozone. WIPO WO2013144483A1, 18 March 2013.

76. Glattfeld, J.W.E.; Gershon, S. The Catalytic Dehydrogenation of Sugar Alcohols. J. Am. Chem. Soc. 1938, 60, 2013-2023. [CrossRef]

77. Mehltretter, C.L.; Rist, C.E.; Alexander, B.H. Process for the preparation of D-glucosaccharic acid. U.S. Patent 2472168A, 7 June 1949.

78. Boussie, T.R.; Dias, E.L.; Fresco, Z.M.; Murphy, V.J.; Shoemaker, J.; Archer, R.; Jiang, H. Production of adipic acid and derivatives from carbohydrate-containing materials. WIPO WO2010144862A2, 16 December 2010.

79. van Es, D.S.; van Haveren, J.; Raaijmakers, H.W.C.; van der Klis, F.; van Engelen, G.P.F.M.; Frissen, A.E. Catalytic oxidation of uronic acids to aldaric acids. WIPO WO2013151428A1, 10 October 2013.

80. Hong, C.H.; Kim, S.H.; Kim, Y.G.; Shin, N.R. Method for producing glucaric acid. U.S. Patent 9227904B1, 5 January 2016.

81. Marion, P.; Derrien, E.; Pinel, C.; Besson, M. Process for the preparation of a mixture of aldaric acids or salts thereof. EP3088378A1, 2 November 2016.

82. Dirkn, J.M.H.; van der Baan, H.S.; van den Broen, J.M.A.J.J. The preparation of D-glucaric acid by the oxidation of D-gluconic acid catalysed by platinum on carbon. Carbohydr. Res. 1977, 59, 63-72. [CrossRef]

83. Dirkn, J.M.H.; van der Baan, H.S. The oxidation of gluconic acid with platinum on carbon as catalyst. J. Catal. 1981, 67, 14-20.

84. Besson, M.; Flèche, G.; Fuertes, P.; Gallezot, P.; Lahmer, F. Oxidation of glucose and gluconate on Pt, Pt Bi, and Pt Au catalysts. Recl. Trav. Chim. Pays Bas 1996, 115, 217-221. [CrossRef]

85. Parpot, P.; Nunes, N.; Bettencourt, A.P. Electrocatalytic oxidation of monosaccharides on gold electrode in alkaline medium: Structure-reactivity relationship. J. Electroanal. Chem. 2006, 596, 65-73. [CrossRef]

86. Bujak, P.; Bartczak, P.; Polanski, J. Highly efficient room-temperature oxidation of cyclohexene and d-glucose over nanogold $\mathrm{Au} / \mathrm{SiO}_{2}$ in water. J. Catal. 2012, 295, 15-21. [CrossRef]

87. Colmenares, J.C.; Magdziarz, A. Room temperature versatile conversion of biomass-derived compounds by means of supported $\mathrm{TiO}_{2}$ photocatalysts. J. Mol. Catal. A Chem. 2013, 366, 156-162. [CrossRef] 
88. Colmenares, J.C.; Magdziarz, A.; Chernyayeva, O.; Lisovytskiy, D.; Kurzydłowski, K.; Grzonka, J. Sonication-Assisted Low-Temperature Routes for the Synthesis of Supported $\mathrm{Fe}-\mathrm{TiO}_{2}$ Econanomaterials: Partial Photooxidation of Glucose and Phenol Aqueous Degradation. ChemCatChem 2013, 5, 2270-2277. [CrossRef]

89. van der Klis, F.; Frissen, A.E.; van Haveren, J.; van Es, D.S. Waste not, want not: Mild and selective catalytic oxidation of uronic acids. ChemSusChem 2013, 6, 1640-1645. [CrossRef]

90. Bin, D.; Wang, H.; Li, J.; Wang, H.; Yin, Z.; Kang, J.; He, B.; Li, Z. Controllable oxidation of glucose to gluconic acid and glucaric acid using an electrocatalytic reactor. Electrochim. Acta 2014, 130, 170-178. [CrossRef]

91. Jin, X.; Zhao, M.; Vora, M.; Shen, J.; Zeng, C.; Yan, W.; Thapa, P.S.; Subramaniam, B.; Chaudhari, R.V. Synergistic effects of bimetallic $\mathrm{PtPd} / \mathrm{TiO}_{2}$ nanocatalysts in oxidation of glucose to glucaric acid: Structure dependent activity and selectivity. Ind. Eng. Chem. Res. 2016, 55, 2932-2945. [CrossRef]

92. Lee, J.; Saha, B.; Vlachos, D.G. Pt catalysts for efficient aerobic oxidation of glucose to glucaric acid in water. Green Chem. 2016, 18, 3815-3822. [CrossRef]

93. Megías-Sayago, C.; Carrasco, C.J.; Ivanova, S.; Montilla, F.J.; Galindo, A.; Odriozola, J.A. Influence of the ionic liquid presence on the selective oxidation of glucose over molybdenum based catalysts. Catal. Today 2016, 278, 82-90. [CrossRef]

94. Solmi, S.; Morreale, C.; Ospitali, F.; Agnoli, S.; Cavani, F. Oxidation of D-glucose to glucaric acid using Au/C catalysts. ChemCatChem 2017, 9, 2797-2806. [CrossRef]

95. Derrien, E.; Mounguengui-Diallo, M.; Perret, N.; Marion, P.; Pinel, C.; Besson, M. Aerobic oxidation of glucose to glucaric acid under alkaline-free conditions: Au-based bimetallic catalysts and the effect of residues in a hemicellulose hydrolysate. Ind. Eng. Chem. Res. 2017, 56, 13175-13189. [CrossRef]

96. Purushothaman, R.K.P.; van der Klis, F.; Frissen, A.E.; van Haveren, J.; Mayoral, A.; van der Bent, A.; van Es, D.S. Base-free selective oxidation of pectin derived galacturonic acid to galactaric acid using supported gold catalysts. Green Chem. 2018, 20, 2763-2774. [CrossRef]

97. Armstrong, R.D.; Hirayama, J.; Knight, D.W.; Hutchings, G.J. Quantitative Determination of Pt-Catalyzed d-Glucose Oxidation Products Using 2D NMR. ACS Catal. 2019, 9, 325-335. [CrossRef]

98. Chen, R.; Yang, C.; Zhang, Q.; Zhang, B.; Deng, K. Visible-light-driven selective oxidation of glucose in water with H-ZSM-5 zeolite supported biomimetic photocatalyst. J. Catal. 2019, 374, 297-305. [CrossRef]

99. Besson, M.; Lahmer, F.; Gallezot, P.; Fuertes, P.; Fleche, G. Catalytic Oxidation of Glucose on Bismuth-Promoted Palladium Catalysts. J. Catal. 1995, 152, 116-121. [CrossRef]

100. Mojzita, D.; Wiebe, M.; Hilditch, S.; Boer, H.; Penttilä, M.; Richard, P. Metabolic engineering of fungal strains for conversion of D-galacturonate to meso-galactarate. Appl. Environ. Microbiol. 2010, 76, 169-175. [CrossRef] [PubMed]

101. Hassid, W.Z.; Putman, E.W. Transformation of sugars in plants. Annu. Rev. Plant Biol. 1950, 1, 109-124. [CrossRef]

102. Lin, T.-Y.; Hassid, W.Z. Pathway of alginic acid synthesis in the marine brown alga, Fucus gardneri silva. J. Biol. Chem. 1966, 241, 5284-5297. [PubMed]

103. Nyvall, P.; Corre, E.; Boisset, C.; Barbeyron, T.; Rousvoal, S.; Scornet, D.; Kloareg, B.; Boyen, C. Characterization of mannuronan C-5-epimerase genes from the brown alga Laminaria digitata. Plant Physiol. 2003, 133, 726-735. [CrossRef] [PubMed]

104. Rehm, B.H.A. Bacterial polymers: Biosynthesis, modifications and applications. Nat. Rev. Microbiol. 2010, 8, 578-592. [CrossRef] [PubMed]

105. Zhang, P.; Shao, Z.; Jin, W.; Duan, D. Comparative characterization of two GDP-mannose dehydrogenase genes from Saccharina japonica (Laminariales, Phaeophyceae). BMC Plant Biol. 2016, 16, 62. [CrossRef] [PubMed]

106. Moon, T.S.; Yoon, S.-H.; Lanza, A.M.; Roy-Mayhew, J.D.; Prather, K.L.J. Production of glucaric acid from a synthetic pathway in recombinant Escherichia coli. Appl. Environ. Microbiol. 2009, 75, 589-595. [CrossRef] [PubMed]

107. Lippow, S.M.; Moon, T.S.; Basu, S.; Yoon, S.-H.; Li, X.; Chapman, X.; Robison, K.; Lipovšek, D.; Prather, K.L.J. Engineering enzyme specificity using computational design of a defined-sequence library. Chem. Biol. 2010, 17, 1306-1315. [CrossRef] [PubMed]

108. Shiue, E.; Prather, K.L.J. Improving D-glucaric acid production from myo-inositol in E. coli by increasing MIOX stability and myo-inositol transport. Metab. Eng. 2014, 22, 22-31. [CrossRef] 
109. Shiue, E.; Brockman, I.M.; Prather, K.L.J. Improving product yields on D-glucose in Escherichia coli via knockout of $p g i$ and $z w f$ and feeding of supplemental carbon sources. Biotechnol. Bioeng. 2015, 112, 579-587. [CrossRef]

110. Reizman, I.M.B.; Stenger, A.R.; Reisch, C.R.; Gupta, A.; Connors, N.C.; Prather, K.L.J. Improvement of glucaric acid production in E. coli via dynamic control of metabolic fluxes. Metab. Eng. Commun. 2015, 2, 109-116. [CrossRef]

111. Gupta, A.; Hicks, M.A.; Manchester, S.P.; Prather, K.L.J. Porting the synthetic D-glucaric acid pathway from Escherichia coli to Saccharomyces cerevisiae. Biotechnol. J. 2016, 11, 1201-1208. [CrossRef] [PubMed]

112. Gupta, A.; Reizman, I.M.B.; Reisch, C.R.; Prather, K.L.J. Dynamic regulation of metabolic flux in engineered bacteria using a pathway-independent quorum-sensing circuit. Nat. Biotechnol. 2017, 35, 273-279. [CrossRef] [PubMed]

113. Schoevaart, R.; Kieboom, T. Galactose dialdehyde: The forgotten candidate for a protein cross-linker? Carbohydr. Res. 2001, 334, 1-6. [CrossRef]

114. Schoevaart, R.; Kieboom, T. Galactose dialdehyde as potential protein cross-linker: Proof of principle. Carbohydr. Res. 2002, 337, 899-904. [CrossRef]

115. Schoevaart, R.; Kieboom, T. Application of galactose oxidase in chemoenzymatic one-pot cascade reactions without intermediate recovery steps. Top. Catal. 2004, 27, 3-9. [CrossRef]

116. Sun, L.; Bulter, T.; Alcalde, M.; Petrounia, I.P.; Arnold, F.H. Modification of galactose oxidase to introduce glucose 6-oxidase activity. ChemBioChem 2002, 3, 781-783. [CrossRef]

117. Moon, T.S.; Nielsen, D.R.; Prather, K.L.J. Sensitivity analysis of a proposed model mechanism for newly created glucose-6-oxidases. AIChE J. 2012, 58, 2303-2308. [CrossRef]

118. Richard, P.; Hilditch, S. D-galacturonic acid catabolism in microorganisms and its biotechnological relevance. Appl. Microbiol. Biotechnol. 2009, 2, 597-604. [CrossRef]

119. Pedrolli, D.B.; Monteiro, A.C.; Gomes, E.; Carmona, E.C. Pectin and pectinases: Production, characterization and industrial application of microbial pectinolytic enzymes. Open Biotechnol. J. 2009, 3, 9-18. [CrossRef]

120. Voragen, A.G.J.; Coenen, G.-J.; Verhoef, R.P.; Schols, H.A. Pectin, a versatile polysaccharide present in plant cell walls. Struct. Chem. 2009, 20, 263-275. [CrossRef]

121. Babbar, N.; Dejonghe, W.; Gatti, M.; Sforza, S.; Elst, K. Pectic oligosaccharides from agricultural by-products: Production, characterization and health benefits. Crit. Rev. Biotechnol. 2016, 36, 594-606. [CrossRef] [PubMed]

122. D'Ayala, G.G.; Malinconico, M.; Laurienzo, P. Marine derived polysaccharides for biomedical applications: Chemical modification approaches. Molecules 2008, 13, 2069-2106. [CrossRef] [PubMed]

123. Vera, J.; Castro, J.; Gonzalez, A.; Moenne, A. Seaweed polysaccharides and derived oligosaccharides stimulate defense responses and protection against pathogens in plants. Mar. Drugs 2011, 9, 2514-2525. [CrossRef] [PubMed]

124. Foley, P.M.; Beach, E.S.; Zimmerman, J.B. Algae as a source of renewable chemicals: Opportunities and challenges. Green Chem. 2011, 13, 1399-1405. [CrossRef]

125. Kerton, F.M.; Liu, Y.; Omari, K.W.; Hawboldt, K. Green chemistry and the ocean-based biorefinery. Green Chem. 2013, 15, 860-871. [CrossRef]

126. Michalak, I.; Chojnacka, K. Algae as production systems of bioactive compounds. Eng. Life Sci. 2015, 15, 160-176. [CrossRef]

127. Lee, K.Y.; Mooney, D.J. Alginate: Properties and biomedical applications. Prog. Polym. Sci. 2012, 37, 106-126. [CrossRef] [PubMed]

128. Saha, B.C. Hemicellulose bioconversion. J. Ind. Microbiol. Biotechnol. 2003, 30, 279-291. [CrossRef] [PubMed]

129. Scheller, H.V.; Ulvskov, P. Hemicelluloses. Annu. Rev. Plant Biol. 2010, 61, 263-289. [CrossRef]

130. Lahaye, M.; Robic, A. Structure and functional properties of ulvan, a polysaccharide from green seaweeds. Biomacromolecules 2007, 8, 1765-1774. [CrossRef] [PubMed]

131. Benz, J.P.; Protzko, R.J.; Andrich, J.M.S.; Bauer, S.; Dueber, J.E.; Somerville, C.R. Identification and characterization of a galacturonic acid transporter from Neurospora crassa and its application for Saccharomyces cerevisiae fermentation processes. Biotechnol. Biofuels 2014, 7, 20. [CrossRef] [PubMed]

132. Biz, A.; Sugai-Guérios, M.H.; Kuivanen, J.; Maaheimo, H.; Krieger, N.; Mitchell, D.A.; Richard, P. The introduction of the fungal D-galacturonate pathway enables the consumption of D-galacturonic acid by Saccharomyces cerevisiae. Microb. Cell Fact. 2016, 15, 144. [CrossRef] [PubMed] 
133. Kuivanen, J.; Wang, Y.M.J.; Richard, P. Engineering Aspergillus niger for galactaric acid production: Elimination of galactaric acid catabolism by using RNA sequencing and CRISPR/Cas9. Microb. Cell Fact. 2016, 15, 210. [CrossRef] [PubMed]

134. Barth, D.; Wiebe, M.G. Enhancing fungal production of galactaric acid. Appl. Microbiol. Biotechnol. 2017, 101, 4033-4040. [CrossRef] [PubMed]

135. Leh, D.S.; Biz, A.; de Paula, D.H.F.; Richard, P.; Gonçalves, A.G.; Noseda, M.D.; Mitchell, D.A.; Krieger, N. Conversion of citric pectin into D-galacturonic acid with high substrate loading using a fermented solid with pectinolytic activity. Biocatal. Agric. Biotechnol. 2017, 11, 214-219. [CrossRef]

136. Paasikallio, T.; Huuskonen, A.; Wiebe, M.G. Scaling up and scaling down the production of galactaric acid from pectin using Trichoderma reesei. Microb. Cell Fact. 2017, 16, 119. [CrossRef] [PubMed]

137. Sakuta, R.; Takeda, K.; Igarashi, K.; Ohno, H.; Nakamura, N. Pyrroloquinoline quinone-dependent glucose dehydrogenase anode: D-Galacturonic acid oxidation and galactaric acid production. J. Mol. Catal. B Enzym. 2016, 133, S76-S79. [CrossRef]

138. Sakuta, R.; Takeda, K.; Igarashi, K.; Ohno, H.; Nakamura, N. Enzymes suitable for biorefinery to coproduce hexaric acids and electricity from hexuronic acids derived from biomass. Energy Technol. 2018, 6, $273-279$. [CrossRef]

139. Sakuta, R. Simultaneous production of biomass-derived platform chemicals and electricity. Ph.D. Thesis, Tokyo University of Agriculture and Technology, Tokyo, Japan, 27 March 2018.

140. Amaniampong, P.N.; Karam, A.; Trinh, Q.T.; Xu, K.; Hirao, H.; Jérôme, F.; Chatel, G. Selective and catalyst-free oxidation of D-glucose to D-glucuronic acid induced by high-frequency ultrasound. Sci. Rep. 2017, 7, 40650. [CrossRef] [PubMed]

141. Wojcieszak, R.; Cuccovia, I.M.; Silva, M.A.; Rossi, L.M. Selective oxidation of glucose to glucuronic acid by cesium-promoted gold nanoparticle catalyst. J. Mol. Catal. A Chem. 2016, 422, 35-42. [CrossRef]

(C) 2019 by the authors. Licensee MDPI, Basel, Switzerland. This article is an open access article distributed under the terms and conditions of the Creative Commons Attribution (CC BY) license (http://creativecommons.org/licenses/by/4.0/). 